\title{
Biomarkers and surrogate endpoints in the glaucomatous optic neuropathy: new developments and a review
}

\author{
Biomarcadores e desfechos substitutos na neuropatia óptica \\ glaucomatosa: novos desenvolvimentos e uma revisão
}

Niro Kasahara ${ }^{1}$

\begin{abstract}
Glaucoma is a group of progressive optic neuropathies that have in common a slow progressive degeneration of retinal ganglion cells and their axons, resulting in a distinct appearance of the optic disc and a concomitant pattern of visual loss. Biomarkers are characteristics objectively measured and evaluated as indication of normal biologic processes, pathogenic processes, or pharmacologic responses to a therapeutic intervention. Several biological markers have been implicated with glaucoma, especially genetics, proteomics, autoimmune and other molecular biomarkers, although, most awaits clinical validation. There are clear potential benefits in using biomarkers. Information can be obtained earlier, faster, and less costly. This review summarizes the latest developments and approaches in glaucoma biomarkers and its possible uses in the diagnosis, staging, and as predictors of response to treatment.
\end{abstract}

Keywwords: Glaucoma; Optic nerve diseases; Biological makers

\section{ReSUMO}

O glaucoma compreende um grupo de neuropatias ópticas progressivas que tem em comum a degeneração lenta e progressiva das células ganglionares e seus axônios, resultando em aparência única do disco óptico e, simultaneamente, um padrão correspondente de perda visual. Biomarcadores são características medidas objetivamente e avaliadas como indicadores de processo biológico normal, processos patológicos ou respostas farmacológicas à uma intervenção terapêutica. Vários marcadores biológicos foram associados com glaucoma, especialmente os genéticos, proteômicos, autoimunes e outros biomarcadores moleculares, embora a maioria ainda necessite de validação clínica. Existem potenciais benefícios em usar biomarcadores. Informações podem ser obtidas mais precocemente, de forma mais rápida e menos onerosa. Esta revisão resume os últimos avanços e métodos em biomarcadores de glaucoma e seu possível uso no diagnóstico, estadiamento e como preditores da resposta ao tratamento.

Descritores: Glaucoma; Doenças do nervo óptico; Marcadores biológicos

\footnotetext{
1 Departamento de Oftalmologia, Irmandade da Santa Casa de Misericórdia de São Paulo; Faculdade de Ciências Médicas da Santa Casa de São Paulo, São Paulo, SP, Brazil.

The authoes declare no conflicts of interest

Received for publication 21/08/2014 - Accepted for publication 17/12/2014
} 
B iomarkers are characteristics objectively measured and evaluated as indication of normal biologic processes, pathogenic processes, or pharmacologic responses to a therapeutic intervention. ${ }^{(1)}$ Although what the marker marks is clearly defined as being intrinsic, the marker itself can be either intrinsic or extrinsic. Intrinsic markers can be physical (clinical or radiographic) or laboratorial (physiological, pharmacological, genetic, biochemical, etc.). An example of an extrinsic marker is cigarette consumption in lung cancer.(2) $\mathrm{A}$ surrogate marker or surrogate endpoint has been defined as a biomarker intended to substitute for a clinical endpoint, the latter being a characteristic or variable that reflects how a patient feels, functions, or survives. ${ }^{(1)}$

Both biomarkers and surrogate endpoints can be used in diagnosing, staging, and monitoring disease, and in determining its response to therapy.

The difference between a biomarker and surrogate endpoint is that a biomarker is a "candidate" surrogate marker, whereas a surrogate marker is a test used, and taken, as a measure of the effects of a specific treatment. ${ }^{(3)}$ Biomarkers are often cheaper and easier to measure than true endpoints and can be measured more quickly and earlier. There may also be ethical issues associated with measuring true endpoints. For example, in paracetamol overdose it is unethical to wait for evidence of liver damage before deciding whether or not to treat a patient; instead, a pharmacological biomarker, the plasma paracetamol concentration, is used to predict whether treatment is required. ${ }^{(2)}$

Biomarkers can be used at any point in the chain of events that leads from the pathogenesis of a disease to its clinical manifestations, whether at the molecular, cellular, or organ levels. Likewise, a therapy might be developed to tackle any one of these links, in order to try to treat the disease. Any measurement short of the actual outcome could be regarded as a surrogate endpoint biomarker. However, although all surrogate endpoints are biomarkers, not all biomarkers are useful surrogate endpoints. ${ }^{(2)}$

Surrogate endpoints are used in clinical trials and, as such, it is defined as a response variable for which a test of the null hypothesis of no relationship to the treatment groups under comparison is also a valid test of the corresponding null hypothesis based on the true endpoint. ${ }^{(4)}$ It's use, however, introduces heterogeneous variance and the problem of regression to the mean.

In clinical practice, biomarkers are used frequently and without notice. In a patient with cancer, a clinician measures the time to relapse as a surrogate endpoint for survival time. Ophthalmologists measure intraocular pressure (IOP) instead of loss of vision in patients with glaucoma. Physicians use biomarkers to stage disease (e.g., the number of lymph nodes affected by cancer), in diagnosis (e.g., magnetic resonance imaging, electrocardiography, and autoimmune antibodies), and to monitor the progress of a disease or its treatment (e.g., serum glucose concentration and blood pressure).(2)

The increased sensitivity and the developments of genomic, proteomic, and metabolomic research techniques have caused the potential to identify molecules that may serve as potentially useful markers, including (1) markers for early detection of a disease, (2) markers to predict disease severity, (3) markers to predict the rate of disease progression, and (4) markers to serve as predictors of response to treatment. ${ }^{(5)}$
Glaucoma is a group of progressive optic neuropathies that have in common a slow progressive degeneration of retinal ganglion cells and their axons, resulting in a distinct appearance of the optic disc and a concomitant pattern of visual loss. ${ }^{(6)}$ It is estimated that glaucoma affects more than 66 million individuals worldwide with at least 6.8 million bilaterally blind. ${ }^{(7)}$ Although not completely understood, it is a multifactorial complex neurodegenerative disease triggered by different factors including mechanical stress due to intraocular pressure, decreased blood flow to retina, reperfusion injury, oxidative stress, glutamate excitotoxicity, and aberrant immune response.

The discovery of clinically useful biomarkers in glaucoma is constantly expanding and includes from genes to proteomic markers, and analyses of serum antibodies to retina and optic nerve proteins. We summarize herein the current knowledge regarding the factors related to the diagnosis, progression, and response to treatment of glaucoma, which have not been definitely established but represent biomarker candidates to be validated. These markers include clinical, genetic, proteomic, autoimmune, and neurodegenerative candidates yet to be corroborated.

\section{Clinical biomarkers}

Automated perimetry, IOP, optic disk, and retinal nerve fiber layer are surrogate markers for glaucomatous optic neuropathy used in clinical practice and as outcome measures in research. From another standpoint, biomarkers are biological quantitative measurements that may differentiate suspected disease from healthy individuals, and predict the course of disease, or treatment response. So far, we recognize some of the risk factors for glaucoma, such as elevated IOP, although it is not always present in every patient. A combination of two or more biomarkers such as optic nerve structure, visual function and IOP, is a "biosignature" of glaucoma disease, just as measurements of high density lipoprotein (HDL), low density protein (LDL), and cholesterol have become biosignatures of cardiovascular disease. ${ }^{(8)}$

\section{Intraocular pressure}

A number of randomized clinical trials have convincingly shown that elevated IOP is the leading risk factor for glaucoma development and that IOP reduction can significantly reduce the incidence and progression of the disease. However, IOP can be deceiving in that it is not a defining criterion for primary open-angle glaucoma (POAG). Population surveys show that up to $50 \%$ of open-angle glaucoma patients have an IOP of $21 \mathrm{~mm}$ $\mathrm{Hg}$ or lower. ${ }^{(9,10)}$ Besides, the effect of IOP fluctuation, either diurnal or long-term visit to visit, on the risk of developing POAG is still controversial. ${ }^{(11)}$

Some investigators propose a joint analysis approach to assess whether variability of IOP as a biomarker is independently predictive of clinical outcomes. Using data from two long-term clinical trials of the efficacy of IOP lowering medication in the prevention of glaucoma (the Ocular Hypertension Treatment Study - OHTS and the European Glaucoma Prevention Study - EGPS), they determined if longterm IOP fluctuation is independently predictive of POAG. A linear mixed model incorporating patient-specific variance describes the trajectory of IOP, and its association with the time to POAG is assessed using both semi-parametric and full parametric survival models. Substantively, the authors results show that IOP variability is independently predictive of POAG 
in the OHTS, and the subjects with high IOP fluctuation have an increased risk of developing POAG. ${ }^{(12)}$

\section{Visual function: automated perimetry}

The loss of retinal ganglion cells in glaucoma leads to characteristic visual field defects as evaluated by automated perimetry, although a great amount of axons has to be lost before initial visual field defects can be detected. To patients, visual function may be the clearest marker of glaucoma. There seems to be a clear relationship between visual function and quality of life. ${ }^{(13)}$ Automated perimetry is a particularly useful clinical biomarker to predict disease severity, since the visual fields of apatient immediately give an appraisal about the amount of damage, and also the amount of residual vision that is available before the patient will suffer definite and clear loss of quality of life.

Nevertheless, automated perimetry do have some limitations as a biomarker. Visual field defects are not disease specific. Although visual field defects in glaucoma follows typically a ganglion cell loss pattern, other optic neuropathies do cause ganglion cell loss and visual field defects similar to glaucoma. ${ }^{(14)}$ The visual field index (VFI) has been developed to evaluate progression of glaucoma in time. ${ }^{(15)}$ As a marker to predict the rate of disease progression, automated perimetry is not ideal, since it is usually necessary to perform a number of tests to assess progression. Besides, as a psychophysical test it is dependent on patient response and can be very variable from one exam from another. Automated perimetry is not a useful marker for early detection of a disease since a large amount of ganglion cells must be lost before initial visual field defects can be detected.

\section{Structural measures: optic nerve and retinal nerve fiber layer}

Direct assessment of the optic nerve and the retinal nerve fiber layer is of paramount importance in glaucoma diagnosis and progression. Progressive optic disc damage is highly predictive for the development of functional loss in glaucoma. Some changes in the optic disk are typical of the glaucomatous optic neuropathy, however, there is a number of patients with suspicious looking disks in which the structural evaluation per se is not enough for diagnosis. Although ephemeral and not very frequent, disk hemorrhage is a very typical feature in glaucoma patients and almost pathognomonic of glaucoma. It may be a marker of rapid glaucoma progression, in that localized subclinical structural change predisposes to disk hemorrhage, after which subsequent disease progression is accelerated, and recurrent optic disk hemorrhages are related to rapid structural progression of glaucomatous damage. ${ }^{(16)}$ The development of new imaging devices provides better access to view the optic disk and the nerve fiber layer as potential biomarkers. Optic coherence tomography is a useful device to assess the optic nerve, and careful monitoring of the optic disc appearance is important to evaluate glaucoma progression. However, whether changes detected by imaging instruments are associated with future progression remains a key question and the ability to longitudinally evaluate imaging instruments is difficult as the technology is always evolving.

\section{Genetic biomarkers}

Family history is a risk factor of glaucoma. In fact, about $20 \%$ of glaucoma patients have family history of the disease and the prevalence of open-angle glaucoma increases up to $13.5 \%$ among relatives of glaucoma patients indicating an important genetic component. ${ }^{(17,18)}$ Genetic biomarkers might be invaluable tools to identify individuals at risk for disease as well as serving to measure the outcomes of therapies. One drawback is that no all genes can function as biomarkers. In order to have a large effect size the allele frequency has to be low; conversely, a high allele frequency has low effect size. Besides, most gene mutations and polymorphism are population specific; so one particular gene mutation in Europeans descendents may not be implicated in an African population.

Model-dependent linkage analyses using multiplex POAG pedigrees have generated a number of potential loci ( $G L C 1 A-$ $G L C 1 H$ and $G L C 1 L$ ) however, only three genes have been recognized.

$M Y O C$ (myocilin) was the first gene identified from the GLC1A locus. ${ }^{(19,20)}$ Myocilin is an extracellular protein of unknown ocular function. Missense mutations account for $3 \%$ to $5 \%$ of POAG cases. ${ }^{(21,22)}$ The underlying genetic mechanism is possibly gain-of function or dominant-negative effect, since the loss of protein function does not result in glaucoma. ${ }^{(23-25)}$ The disease-associated missense changes reduce the solubility of the protein, causing it to aggregate in the endoplasmic reticulum and preventing its secretion to the extracellular matrix. ${ }^{(26)}$ The absence of protein does not cause disease, however, intracellular accumulation of myocilin aggregates may sensitize trabecular meshwork cells to apoptosis. ${ }^{(27)}$

The second gene optineurin $(O P T N)$ was identified at GLC1E (10p15-p14) and is primarily responsible for rare cases of familial normal tension glaucoma. ${ }^{(28-30)}$ Optineurin may possibly influence ganglion cell apoptosis directly through rab8 signaling. ${ }^{(31,32)}$

WD repeat domain $36(W D R 36)$ at $G L C 1 G(5 \mathrm{q} 21.3-\mathrm{q} 22.1)$ seems to be related to POAG severity in some cases, although it is neither necessary nor sufficient for disease development. ${ }^{(33,34)}$ A zebrafish homolog of WDR36 stimulates apoptosis mediated by $\mathrm{p} 53$, implying a possible role for the gene in retinal ganglion cell susceptibility to apoptotic cell death. ${ }^{(35)}$

Genome-wide scans using nonparametric linkage methods in different populations of POAG pedigrees identified 10 genomic regions that may harbor POAG susceptibility genes $(2 \mathrm{p} 14,2 \mathrm{q} 33$ 34, 10-12-p13, 14q11-q22, 17p13, 17q25, 19q12-q14). ${ }^{(36-38)}$ Using ordered subset analysis with the mean family age of onset as a covariate, a follow-up study of the scan performed on European descent pedigrees, distinguished some families with significant linkage to $15 \mathrm{q} 11-\mathrm{q} 13$, designated $G L C 1 I^{(39)}$

TANK-binding kinase 1 is an enzyme encoded by $T B K 1$ that can mediate NFKB activation in response to certain growth factors. The gene is specifically expressed in retinal ganglion cells affected by glaucoma. Located in chromosome 12q14, duplications of the gene were discovered in normal tension glaucoma patients. This duplication leads to increased transcription of $T B K 1 .^{(40,41)}$ Besides, TBK1 associates with the product of OPTN. ${ }^{(42)}$ Nevertheless, this is a rare observation, given that, only $1 \%$ of patients displayed duplication of the TBK1 gene in a multicenter case-control study. ${ }^{(43)}$

Useful genetic screening tests for POAG are not available. ${ }^{(44)}$ Currently only $30 \%$ of individuals at risk for earlyonset forms of glaucoma cases can be identified. ${ }^{(45)}$ Continuing research using genome-wide association in large population may reveal new genetic biomarkers and useful screening tests. ${ }^{(46)}$ 
In order to use genes as biomarkers, one needs to have causative genes or to have genes that are associated with disease. At present, gene-based risk prediction and prognosis at early stages of the disease are possible; however, studies that isolate genes associated with late onset forms of glaucoma are still underway. Most of the genes associated with glaucoma are causative, so that, a molecular diagnosis and genetic counseling with families who carry disease are possible. Future research will aim to target newly identified genes with clinical phenotypes and outcomes, to identify genes associated with POAG, and to correlate genetic variation with disease, clinical outcome, and treatment response.

\section{Proteomic biomarkers}

The term proteomics was first introduced in 1994 for the aim of global characterization of a proteome (referring the proteins expressed by the genome), including protein expression, structure, modifications, functions, and interactions. ${ }^{(47)}$ The proteome is the entire set of proteins, produced or modified by an organism or system. ${ }^{(48)}$

Proteomics is one of the most important post-genomic approaches to improve the understanding of gene function. Nevertheless, when compared to genome, proteome is a much more complex and dynamic system. Although proteins provide the most important clues to disease mechanisms, their analysis is difficult due to large diversity in properties, such as molecular size, dynamic range in quantity, and their hydrophilicity or hydrophobicity. ${ }^{(49)}$ Conversely, since blood samples can be easily collected, the proteins detectable in serum or plasma have formed the basis of commonly used tests to screen and monitor disease biomarkers in various fields.

Proteomics is highly useful in the identification of candidate biomarkers (proteins in body fluids that are of value for diagnosis), identification of the bacterial antigens that are targeted by the immune response, and identification of possible immunohistochemistry markers of infectious or neoplastic diseases. ${ }^{(50)}$ Recent studies of glaucoma using proteomics analysis techniques have resulted in a lists of differentially expressed proteins in human glaucoma and animal models. The global analysis of protein expression in glaucoma has been followed by cell-specific proteome analysis of both retinal ganglion cells and astrocytes. The proteomics data have also guided targeted studies to identify post-translational modifications and protein-protein interactions during glaucomatous neurodegeneration. In addition, recent applications of proteomics have provided a number of potential biomarker candidates. ${ }^{(49)}$

To date, most of the studies in glaucoma molecular biomarkers comprise the studies of autoantibodies and their target antigens. A panel of antigenic proteins that elicit serum immunoreactivity at a high frequency among glaucoma patients can provide an effective tool for biomarker screening. ${ }^{(49)}$ However, a much lower abundance of most protein biomarkers than some disease-irrelevant serum proteins poses a challenge of serum biomarker detection.

Currently, 22 proteins were detected in glaucoma patients and included immune mediators and components of cell death signaling which may serve as biomarker candidates (Table 1). ${ }^{(49)}$ Nevertheless, the clinical validation of candidate molecules still poses a major challenge. Large studies of heterogeneous cohorts for appropriate statistical power and blinding are deemed necessary to eliminate false positives and to calculate the sensitivity and specificity of candidate molecules for clinical prediction. ${ }^{(51,52)}$ Besides, given the highly complex pathogenesis and the characteristic inter-patient heterogeneity of glaucoma, a panel of biomarkers, rather than a single biomarker, is needed to provide appropriate sensitivity and specificity needed.(49)

\section{Table 1. Potencial glaucoma protein biomarkers candidates (adapted from Tezel ${ }^{49}$ ).}

\begin{tabular}{|c|c|}
\hline Protein name & cession number* \\
\hline $\begin{array}{l}\text { A-kinase anchor protein } 10 \text {, } \\
\text { mitochondrial precursor }\end{array}$ & gil21493033 \\
\hline Actin, cytoplasmic & gi|45011885 \\
\hline $\begin{array}{l}\text { Heterogenius nuclear } \\
\text { ribonucleoprotein C-like }\end{array}$ & gil282396082 \\
\hline $\begin{array}{l}\text { Insulin-like growth factor } \\
2 \text { mRNA-binding protein } 2 \text { isoform } b\end{array}$ & gil56118219 \\
\hline $\begin{array}{l}\text { Rho guanine nucleotide exchange } \\
\text { factor } 40\end{array}$ & gil50843837 \\
\hline Toll-like receptor 8 precursor & gil20302168 \\
\hline $\begin{array}{l}\text { Tripartite motif-containing } \\
\text { protein } 5 \text { isoform delta }\end{array}$ & gil203046698 \\
\hline $\begin{array}{l}\text { RNA polymerase I-specific } \\
\text { transcription initiation factor RRN3 }\end{array}$ & gil93102377 \\
\hline $\begin{array}{l}\text { Minichromosome maintenance complex } \\
\text { component-like isoform a }\end{array}$ & gil209954821 \\
\hline Hypothetical protein LOC100510472 & gil310133112 \\
\hline $\begin{array}{l}\text { GRIP and coiled-coil } \\
\text { domain-containing protein } 2\end{array}$ & gil31563507 \\
\hline $\begin{array}{l}\text { DNAJ homolog subfamily } \mathrm{C} \\
\text { member } 7 \text { isoform } 2\end{array}$ & gil221219056 \\
\hline Zinc finger protein $804 \mathrm{~B}$ & gil31791053 \\
\hline $\begin{array}{l}\text { 1-phosphatidylinositol-4,5-biphsophate } \\
\text { phosphodiesterase gamma-1 isoform b }\end{array}$ & gil33598946 \\
\hline $\begin{array}{l}\text { C-Jun-amino-terminal } \\
\text { kinase-interacting protein } 1\end{array}$ & gi|4885433 \\
\hline Kinesin-like protein KIF17 isoform a & gil170784807 \\
\hline $\begin{array}{l}\text { NACTH, LRR and PYD } \\
\text { domains-containing protein } 6\end{array}$ & gil21264320 \\
\hline Sialic acid-binding Ig-like lectin 5 precursor & gil4502659 \\
\hline $\begin{array}{l}\text { Testis-specific serine/ } \\
\text { threonine-protein kinase } 2\end{array}$ & gil194294513 \\
\hline Poly [ADP-ribose] polymerase 1 & gil156523968 \\
\hline $\begin{array}{l}\text { NACTH, LRR and PYD } \\
\text { domains-containing protein } 8\end{array}$ & gil33667040 \\
\hline $\begin{array}{l}\text { Protocadherin gamma-A11 } \\
\text { isoform } 1 \text { precursor }\end{array}$ & gil11128039 \\
\hline
\end{tabular}

* GenInfo Identifier (gi) was an early system used in bioinformatics to access GenBank and related databases. A gi number was assigned to each nucleotide and protein sequence accessible through the NCBI search systems, and was a means of tracking changes to the sequence. It is an unique identifier given to a DNA or protein sequence record to allow for tracking of different versions of that sequence record and the associated sequence over time in a single data repository. 


\section{Autoimmune biomarkers}

There is growing evidence implying an autoimmune involvement in the pathogenesis of glaucoma. A number of studies provide fundamental insights into neurodegenerative properties of autoreactive IgG antibodies, which impair retinal ganglion cells (RGC) survival by specific binding, and assume direct and indirect triggered pathways for cell death in vivo. ${ }^{(53)}$

Additional evidence of the role of autoimmunity in glaucoma is provided by the finding of elevated levels of antibodies against small heat shock proteins (a-A-crystalline, aBcrystalline, and HSP27) in normal tension glaucoma patients. ${ }^{(54,55)}$ Disease-specific changes in complex profiles of naturally occurring $\mathrm{IgG}$ autoantibodies were detected in the sera of glaucoma patients. ${ }^{(56-58)}$ Increased antibody levels (e.g. HSP70, anti-phosphatidylserine, g-enolase, glycosaminoglycans, neuron specific enolase, glutathione-S-transferase, a-fodrin, vimentin, MBP, glial fibrillary acidic protein, and retinal S-antigen) were identified and implicated as player for autoimmunity in glaucoma and also significant and selective downregulations (e.g. anti-GFAP, anti-14-3-3) could be detected in glaucoma patients. ${ }^{(59-68)}$ However, whether the autoantibodies have a causative effect or appear as an epiphenomenon of the disease is yet to be unraveled. The downregulations are possibly related to a loss of natural protective autoimmunity and a disbalance of naturally occurring autoantibodies promoting neurodegenerative processes. ${ }^{(69,70)}$ This unsteadiness may shift the physiological balance of protective immunity into a neuroinflammatory degenerative process leading to a predisposition for glaucoma which raises the question whether elicited autoimmunity can cause RGC loss. ${ }^{(53)}$

There is a controversial debate whether autoantibodies are aberrant and contribute to disease pathogenesis or are beneficial, being part of a protective mechanism. Contradicting the principle that autoantibodies are always associated with pathological conditions, cumulative evidence demonstrate that natural autoantibodies entail protective characteristics and that autoimmunity can be protective in some situations. ${ }^{(71,72)}$ Accordingly, the downregulation of some autoantibodies in glaucoma patients could lead to a loss of protective autoimmunity. ${ }^{(53)}$

As a parameter associated with the presence and severity of specific disease states, autoantibody patterns are useful biomarkers for glaucoma diagnosis before its clinical manifestations. Using mass spectrometry-based proteomics to compare the autoantibody profiles in body fluids (serum, aqueous humor or tears) from patients with glaucoma with those obtained from healthy individuals, autoantibody patterns that are the most discriminating can be classified. ${ }^{(53)}$ Autoantibody profiles are useful laboratory markers for the diagnosis of diseases such as cancer, rheumatoid arthritis and Alzheimer's disease. ${ }^{(73-75)}$ In glaucoma, the complex antibody profiles are stable and consistently exist among different study populations. ${ }^{(65)}$ As described previously, many autoantibody reactivities are significantly increased or decreased in glaucoma patients as compared to non-glaucoma control group. Using a pattern recognition algorithm such as artificial neural networks for unique serum autoantibody patterns, it is possible to differentiate between sera of POAG patients and healthy subjects with a sensitivity and specificity of approximately $93 \%{ }^{(53)}$ Hence, autoantibodies can be highly-specific and accurate useful biomarkers for glaucoma diagnosis by simple blood testing.

\section{Miscellaneous}

Some non-genetic molecular candidate biomarkers includes hormones such as erythropoietin, which exert its neuroprotective effect by reducing the nitric oxide-mediated formation of free radicals or antagonizing their toxicity, and hepcidin that regulates of iron efflux from numerous cell types and is expressed in the Müller cells, photoreceptors, and retinal pigmented epithelium. Table 2 depicts a list of potential nongenetic glaucoma biomarkers. ${ }^{(76)}$

New proteins detected in the aqueous humor of glaucoma patients are involved in molecular events that resemble those that occur during atherosclerosis, such as, endothelial dysfunction, lipoprotein alteration, modification of smooth muscle cell functions, oxidative damage, inflammation, loss of intercellular adhesion, mitochondrial failure, and apoptosis. ${ }^{(77)}$ As a whole, these observations indicate that a remarkable endothelial damage affects the anterior chamber in glaucoma, especially in the trabecular meshwork. From a biological point of view, the anterior chamber is a space that is surrounded by an endothelium and a path by which a liquid travels, so it can be considered as being similar to a vessel. ${ }^{(78)}$ Hence, these new proteins are referred as vascular biomarkers ( Table 2).

\section{Neurodegenerative markers}

Neurodegenerative diseases are slowly progressive and irreversible disorders of the nervous system. Early detection of disease is possible by means of neurochemical measurements and neuroimaging biomarkers specifically related to the pathogenic events. ${ }^{(79,80)}$ Parkinson's and Alzheimer's disease are typical neurodegenerative diseases and although its primary causes are different from the glaucomatous optic neuropathy, they share close similarities in several pathological findings. ${ }^{(81)}$

Retinal ganglion cell bodies are located within the eyeball and its axons emerge the eye forming the optic nerve, chiasm and optic tract. As retinal ganglion cell axons project to the central nervous system, their number within the retrobulbar optic nerve may be a suitable surrogate marker for optic atrophy. ${ }^{(82)}$ Thinning of the retrobulbar optic nerve has been reported both in histological and diagnostic imaging studies suggesting that the diameter of the nerve may correlate with the extent of the optic atrophy. ${ }^{(83-87)}$ High-resolution magnetic resonance imaging (MRI) using an ultra fast HASTE-sequence at $3 \mathrm{~T}$ sequences of the optic nerve can portray axonal loss in the optic nerve comparing closely with the retinal nerve fiber layer-related parameters and could be used as a biomarker for axonal loss in glaucoma. ${ }^{\left({ }^{2}\right)}$ 3-T diffusion tensor imaging of the optic nerve in patients with glaucoma displays good correlation with the retinal nerve fiber layer thickness measured by OCT and may serve as a biomarker of disease severity. ${ }^{(88)}$

The majority of the ganglion cells axons terminate in the lateral geniculate nucleus (LGN), the major relay station between the retina and the visual cortex. ${ }^{\left({ }^{(9)}\right.}$ In an experimental glaucoma model on monkeys, the loss of optic nerve fibers leads to degenerative changes in the LGN, with decrease in number and size of neurons and overall nucleus shrinkage. ${ }^{(90,91)}$ These findings provide evidence of trans-synaptic degeneration in glaucoma, and may be relevant to understanding disease spread in select patients. ${ }^{(81)}$ In vivo MRI evidence of LGN degeneration in human glaucoma is consistent with ex vivo primate and human neuropathological studies. LGN atrophy may be a relevant biomarker of visual system injury and/or progression in some cases of moderate to severe glaucoma patients. ${ }^{(92)}$ 
Table 2. Non genetic candidate biomarkers in glaucoma (adapted from Kokotas et $\mathbf{a l}^{76}$ ).

\begin{tabular}{|c|c|c|}
\hline Candidate biomarker & Type & Source \\
\hline $3 \alpha-\mathrm{HSD}$ & enzyme & blood \\
\hline Ankyrin-2* & protein & $\mathrm{AH}$ \\
\hline ANGPTL7 & protein & $\mathrm{TM}$ and $\mathrm{AH}$ \\
\hline $\begin{array}{l}\text { Antibody for } \\
\text { glycosaminoglycans }\end{array}$ & antibody & serum \\
\hline Antibody for GST & antibody & serum \\
\hline Antibody for NSE & antibody & serum \\
\hline $\begin{array}{l}\text { Antibody for heat } \\
\text { shock proteins }\end{array}$ & antibody & serum \\
\hline $\begin{array}{l}\text { Antibody for anti- } \\
\text {-Helicobacter pylori }\end{array}$ & antibody & $\mathrm{AH}$ and serum \\
\hline $\begin{array}{l}\text { Antibody for Chlamydia } \\
\text { pneumoniae }\end{array}$ & antibody & serum \\
\hline $\mathrm{AP}_{4} \mathrm{~A}$ compound & nucleotide & $\mathrm{AH}$ \\
\hline Apoliprotein B and D* & proteins & $\mathrm{AH}$ \\
\hline BDNF & protein & serum \\
\hline Caspase-14 & enzyme & $\mathrm{AH}$ \\
\hline $\mathrm{CD} 44 \mathrm{H}$ & protein & $\mathrm{TM}$ and $\mathrm{AH}$ \\
\hline Cellular senescence & $\begin{array}{l}\text { antagonistic } \\
\text { pleiotropic response }\end{array}$ & $\mathrm{AH}$ \\
\hline Citrate & nultifunctional acid & Plasma \\
\hline Cystatin C & protein & $\mathrm{AH}$ \\
\hline Cytokines & proteins & TM, AH, and serum \\
\hline ELAM1* & protein & $\mathrm{AH}$ \\
\hline Erythropoietin & hormone & $\mathrm{AH}$ \\
\hline GRP78 & protein & TM \\
\hline $\begin{array}{l}\text { Heat shock } 60 \text { and } 90 \\
\mathrm{kDa}^{*}\end{array}$ & proteins & $\mathrm{AH}$ \\
\hline Hepcidin & hormone & $\mathrm{AH}$ \\
\hline Homocysteine & amino acid & $\begin{array}{l}\text { AH, plasma, and } \\
\text { tear fluid }\end{array}$ \\
\hline Hydroxyproline & imino acid & $\mathrm{AH}$ and plasma \\
\hline Malondialdehyde & aldehyde & AH and plasma \\
\hline $\begin{array}{l}\text { Myoblast determination } \\
\text { protein } 1 *\end{array}$ & protein & $\mathrm{AH}$ \\
\hline Myocilin & protein & $\mathrm{AH}$ and $\mathrm{TM}$ \\
\hline Myogenin* & protein & $\mathrm{AH}$ \\
\hline Myotrophin* & protein & $\mathrm{AH}$ \\
\hline Nitric oxide synthase & enzyme & $\begin{array}{l}\text { TM, Schlemm's canal, } \\
\text { nd collecting channels }\end{array}$ \\
\hline PGDS & enzyme & $\mathrm{AH}, \mathrm{TM}$, and serum \\
\hline Phospholipase $\mathrm{A}_{2}$ & enzyme & $\mathrm{TM}$ \\
\hline Phospholipase $C \beta$ and $\gamma^{*}$ & enzyme & $\mathrm{AH}$ \\
\hline Transferrin & protein & $\mathrm{AH}$ \\
\hline Transthyretin & protein & $\mathrm{AH}$ \\
\hline Tumor necrosis factor $\alpha$ & protein & $\mathrm{AH}$ \\
\hline $\begin{array}{l}\text { Ubiquitin fusion } \\
\text { degradation } 1 \text {-like* }\end{array}$ & protein & $\mathrm{AH}$ \\
\hline $\begin{array}{l}\text { Vasodilator stimulated } \\
\text { phosphoprotein* }\end{array}$ & protein & $\mathrm{AH}$ and $\mathrm{TM}$ \\
\hline
\end{tabular}

AH: aqueous humor;TM: trabecular meshwork; * vascular biomarkers ${ }^{77}$

\section{Future developments and conclusion}

In summary, a biomarker is an anatomic, physiologic, biochemical, or molecular parameter associated with the presence and severity of specific disease states. A biomarker may be detectable and measurable by a variety of methods, including physical examination, laboratory assays, and medical imaging. As a laboratory measurement or physical sign used in therapeutic trials as a substitute for a clinically meaningful endpoint, surrogate endpoints are used as direct measures of how a patient feels, functions, or survives and are expected to predict the effects of the therapy. For validation, a biomarker has to exhibit the capability to capture the net effects of treatment on clinical outcome, using an established scientific framework or body of evidence that elucidates the physiologic, toxicologic, pharmacologic, or clinical significance of the test results. ${ }^{(5)}$

The glaucomatous optic neuropathy encompasses a number of different forms of disease, from childhood, early onset juvenile glaucoma to secondary and adult glaucoma. The discovery of specific biomarkers for each particular glaucoma is deemed necessary and poses a challenge to researchers. Hence, there is probably no single 'ideal' glaucoma biomarker that is going to cover all aspects of clinical disease including early detection, severity prediction, progression, and response to treatment. ${ }^{(5)}$

Despite the plethora of candidates biomarkers discusses in this review, there are still unmet needs for glaucoma. What are the candidate genes that affect connective tissue biomechanics and how would that relate to glaucoma susceptibility? Is there any biomarker that indicates the speed of disease progression? Future research should focus on these issues.

In the near future, as physicians, we expect to be able to establish a patient's risk for POAG using a combination of genetic, clinical and biochemical markers, to assess the ganglion cell disease by novel imaging techniques, and initiate appropriate therapy to restore ganglion cell health. ${ }^{(76)}$

\section{ReFERENCES}

1. NIH Definitions Working Group. Biomarkers and surrogate endpoints in clinical research: definitions and conceptual model. In: Downing GJ, editors. Biomarkers and Surrogate Endpoints. Amsterdam: Elsevier; 2000. p.1-9.

2. Aronson JK. Biomarkers and surrogate endpoints. Br J Clin Pharmacol. 2005; 59(5):491-4.

3. Katz R. Biomarkers and Surrogate Markers: An FDA perspective. NeuroRx. 2004; 1(2):189-95.

4. Prentice RL. Surrogate endpoints in clinical trials: definition and operational criteria. Stat Med. 1989; 8(4):431-40.

5. Bhattacharya SK, Lee RK, Grus FH. Molecular biomarkers in glaucoma. Invest Ophthalmol Vis Sci. 2013; 54(1):121-31.

6. Weinreb RN, Khaw PT. Primary open-angle glaucoma. Lancet. 2004; 363(9422):1711-20.

7. Quigley HA. Number of people with glaucoma worldwide. Br J Ophthalmol. 1996; 80(5):389-93.

8. Gupta N. Playing tag with biomarkers of glaucoma. Open Ophthalmol J. 2009; 3: 29.

9. Tielsch JM, Sommer A, Katz J, Royall RM, Quigley HA, Javitt J. Racial Variations in the Prevalence of Primary Open-angle Glaucoma. The Baltimore Eye Survey. JAMA. 1991; 266(3):369-74.

10. Leske MC, Connell AM, Schachat AP, Hyman L. The Barbados Eye Study. Prevalence of open angle glaucoma. Arch Ophthalmol. 1994; 112(6):821-9. 
11. Singh K, Shrivastava A. Intraocular pressure fluctuations: how much do they matter? Curr Opin Ophthalmol. 2009; 20(1):84-7.

12. Gao F, Miller JP, Miglior S, Beiser JA, Torri V, Kass MA, Gordon MO. A joint model for prognostic effect of biomarker variability on outcomes: long-term intraocular pressure (IOP) fluctuation on the risk of developing primary open-angle glaucoma (POAG). JP J Biostat. 2011; 5(1):73-96.

13. Gutierrez P, Wilson MR, Johnson C, Gordon M, Cioffi GA, Ritch $\mathrm{R}$, et al. Influence of glaucomatous visual field loss on healthrelated quality of life. Arch Ophthalmol. 1997; 115(6):777-84.

14. Hayreh SS, Zimmerman B. Visual field abnormalities in nonarteritic anterior ischemic optic neuropathy: their pattern and prevalence at initial examination. Arch Ophthalmol. 2005; 123(11):1554-62.

15. Bengtsson B, Heijl A. A visual field index for calculation of glaucoma rate of progression. Am J Ophthalmol. 2008; 145(2):343-53.

16. Suh MH, Park KH. Pathogenesis and clinical implications of optic disk hemorrhage in glaucoma. Surv Ophthalmol. 2014; 59(1):19-29.

17. Ray K, Mukhopadhyay A, Acharya M. Recent advances in molecular genetics of glaucoma. Mol Cell Biochem. 2003; 253(1-2): 223-31.

18. van Koolwijk LM, Despriet DD, van Duijn CM, Pardo Cortes LM, Vingerling JR, Aulchenko YS, et al. Genetic contributions to glaucoma: heritability of intraocular pressure, retinal nerve fiber layer thickness, and optic disc morphology. Invest Ophthalmol Vis Sci. 2007; 48(8):3669-76.

19. Stone EM, Fingert JH, Alward WLM. Identification of a gene that causes primary open angle glaucoma. Science. 1997; 275(5300):668-70.

20. Kubota R, Noda S, Wang Y, Minoshima S, Asakawa S, Kudoh J, et al. A novel myosin-like protein (myocilin) expressed in the connecting cilium of the photoreceptor: molecular cloning, tissue expression, and chromosomal mapping. Genomics. 1997; 41(3):360-9.

21. Wiggs JL, Allingham RR, Vollrath D, Jones KH, De La Paz M, Kern J, et al. Prevalence of mutations in TIGR/Myocilin in patients with adult and juvenile primary open-angle glaucoma. Am J Hum Genet. 1998; 63(5):1549-52.

22. Fingert JH, Ho E, Liebmann JM, Yamamoto T, Craig JE, Rait J, et al. Analysis of myocilin mutations in 1703 glaucoma patients from five different populations. Hum Mol Genet. 1999; 8(5):899905 .

23. Wiggs JL, Vollrath D. Molecular and clinical evaluation of a patient hemizygous for TIGR/MYOC. Arch Ophthalmol. 2001; 119(11):1674-8.

24. Kim BS, Savinova OV, Reedy MV, Martin J, Lun Y, Gan L, et al. Targeted disruption of the myocilin gene (Myoc) suggests that human glaucoma-causing mutations are gain of function. Mol Cell Biol. 2001; 21(22):7707-13.

25. Resch ZT, Fautsch MP. Glaucoma-associated myocilin: a better understanding but much more to learn. Exp Eye Res. 2009; 88(4):704-12.

26. Aroca-Aguilar JD, Martínez-Redondo F, Sánchez-Sánchez F, Coca-Prados M, Escribano J. Functional role of proteolytic processing of recombinant myocilin in self-aggregation. Invest Ophthalmol Vis Sci. 2010; 51(1):72-8.

27. Joe MK, Tomarev SI. Expression of myocilin mutants sensitizes cells to oxidative stress-induced apoptosis. Implication for glaucoma pathogenesis. Am J Pathol. 2010; 176(6):2880-90.

28. Rezaie T, Child A, Hitchings R, Brice G, Miller L, Coca-Prados M, et al. Adult-onset primary open-angle glaucoma caused by mutations in optineurin. Science. 2002; 295(5557):1077-79.

29. Hauser MA, Sena DF, Flor J, Walter J, Auguste J, LarocqueAbramson K, et al. Distribution of optineurin sequence variations in an ethnically diverse population of low-tension glaucoma patients from the United States. J Glaucoma. 2006; 15(5):358-63.
30. Aung T, Rezaie T, Okada K, Viswanathan AC, Child AH, Brice G, et al. Clinical features and course of patients with glaucoma with the E50K mutation in the optineurin gene. Invest Ophthalmol Vis Sci. 2005; 46(8):2816-22.

31. Chalasani ML, Radha V, Gupta V, Agarwal N, Balasubramanian D, Swarup G. A glaucoma-associated mutant of optineurin selectively induces death of retinal ganglion cells which is inhibited by antioxidants. Invest Ophthalmol Vis Sci. 2007; 48(4):1607-14.

32. Chibalina MV, Roberts RC, Arden SD, Kendrick-Jones J, Buss F. Rab8-optineurin-myosin VI: analysis of interactions and functions in the secretory pathway. Methods Enzymol. 2008; 438(1):11-24.

33. Monemi S, Spaeth G, DaSilva A, Popinchalk S, Ilitchev E, Liebmann $\mathrm{J}$, et al. Identification of a novel adult onset primary open-angle glaucoma (POAG) gene on 5q22.1. Hum Mol Genet. 2005; 14(6):725-33.

34. Hauser MA, Allingham RR, Linkroum K, Wang J, LaRocqueAbramson K, Figueiredo D, et al. Distribution of WDR36 DNA sequence variants in patients with primary open-angle glaucoma. Invest Ophthalmol Vis Sci. 2006; 47(6):2542-46.

35. Skarie JM, Link BA. The primary open-angle glaucoma gene WDR36 functions in ribosomal RNA processing and interacts with the p53 stress-response pathway. Hum Mol Genet. 2008; 17(6):2474-85.

36. Wiggs JL, Allingham RR, Hossain A, Kern J, Auguste J, DelBono EA, et al. Genome-wide scan for adult onset primary open angle glaucoma. Hum Mol Genet. 2000; 9(7):1109-17.

37. Nemesure B, Jiao X, He Q, Leske MC, Wu SY, Hennis A, et al. A genome-wide scan for primary open-angle glaucoma (POAG): the Barbados Family Study of Open-Angle Glaucoma. Hum Genet. 2003; 112(5-6):600-9.

38. Rotimi CN, Chen G, Adeyemo AA, Jones LS, Agyenim-Boateng $\mathrm{K}$, Eghan BA Jr, et al. Genomewide scan and fine mapping of quantitative trait loci for intraocular pressure on $5 \mathrm{q}$ and $14 \mathrm{q}$ in West Africans. Invest Ophthalmol Vis Sci. 2006; 47(8):3262-67.

39. Allingham RR, Wiggs JL, Hauser ER, Larocque-Abramson KR, Santiago-Turla C, Broomer B, et al. Early adult-onset POAG linked to $15 \mathrm{q} 11-13$ using ordered subset analysis. Invest Ophthalmol Vis Sci. 2005; 46(6):2002-5.

40. Fingert JH, Robin AL, Stone JL, Roos BR, Davis LK, Scheetz $\mathrm{TE}$, et al. Copy number variations on chromosome $12 \mathrm{q} 14$ in patients with normal tension glaucoma. Hum Mol Genet. 2011; 20(12):2482-94.

41. Kawase K, Allingham RR, Meguro A, Mizuki N, Roos B, SolivanTimpe FM, et al. Confirmation of TBK1 duplication in normal tension glaucoma. Exp Eye Res. 2012; 96(1):178-80.

42. Morton S, Hesson L, Peggie M, Cohen P. Enhanced binding of TBK1 by an optineurin mutant that causes a familial form of primary open angle glaucoma. FEBS Lett. 2008; 582(6):997-1002.

43. Ritch R, Darbro B, Menon G, Khanna CL, Solivan-Timpe F, Roos $\mathrm{BR}$, et al. TBK1 gene duplication and normal-tension glaucoma. JAMA Ophthalmol. 2014; 132(5):544-8.

44. Fan BJ, Tam PO, Choy KW, Wang DY, Lam DS, Pang CP. Molecular diagnostics of genetic eye diseases. Clin Biochem. 2006; 39(3):231-9.

45. Mackey DA, Craig JE. Predictive DNA testing for glaucoma: reality in 2003. Ophthalmol Clin North Am. 2003; 16(4):639-45.

46. Fan BJ, Wiggs JL. Glaucoma: genes, phenotypes, and new directions for therapy. J Clin Invest. 2010; 120(9):3064-72.

47. Domon B, Aebersold R. Mass spectrometry and protein analysis. Science. 2006; 312(5771):212-7.

48. Wilkins MR, Pasquali C, Appel RD, Ou K, Golaz O, Sanchez JC, et al. From proteins to proteomes: large scale protein identification by two-dimensional electrophoresis and amino acid analysis. Biotechnology (NY). 1996; 14(1):61-5. 
49. Tezel G. A proteomics view of the molecular mechanisms and biomarkers of glaucomatous neurodegeneration. Prog Retin Eye Res. 2013; 35(1):18-43

50. Ceciliani F, Eckersall D, Burchmore R, Lecchi C. Proteomics in veterinary medicine: applications and trends in disease pathogenesis and diagnostics. Vet Pathol. 2014; 51(2):351-62.

51. Filiou MD, Martins-de-Souza D, Guest PC, Bahn S, Turck CW. To label or not to label: applications of quantitative proteomics in neuroscience research. Proteomics. 2012; 12(4-5):736-47.

52. Matt P, Fu Z, Fu Q, Van Eyk JE. Biomarker discovery: proteome fractionation and separation in biological samples. Physiol Genomics. 2008; 33(1):12-7.

53. Gramlich OW, Bell K, Hohenstein-Blaul NT, Wilding C, Beck S, Pfeiffer N, Grus J. Autoimmune biomarkers in glaucoma patients. Curr Op Pharmacol. 2013; 13(1):90-7.

54. Wax MB, Barrett DA, Pestronk A. Increased incidence of paraproteinemia and autoantibodies in patients with normal pressure glaucoma. Am J Ophthalmol. 1994; 117(5):561-8.

55. Tezel G, Seigel GM, Wax MB. Autoantibodies to small heat shock proteins in glaucoma. Invest Ophthalmol Vis Sci. 1998; 39(12):2277-87.

56. Grus FH, Joachim SC, Hoffmann EM, Pfeiffer N. Complex autoantibody repertoires in patients with glaucoma. Mol Vis. 2004; 10:132-7.

57. Joachim SC, Grus FH, Pfeiffer N. Analysis of autoantibody repertoires in sera of patients with glaucoma. Eur J Ophthalmol. 2003; 13(9-10):752-8.

58. Joachim SC, Pfeiffer N, Grus FH. Autoantibodies in patients with glaucoma: a comparison of IgG serum antibodies against retinal, optic nerve, and optic nerve head antigens. Graefes Arch Clin Exp Ophthalmol. 2005; 243(8):817-23.

59. Joachim SC, Bruns K, Lackner KJ, Pfeiffer N, Grus FH: Antibodies to alpha B-crystallin, vimentin, and heat shock protein 70 in aqueous humor of patients with normal tension glaucoma and $\mathrm{IgG}$ antibody patterns against retinal antigen in aqueous humor. Curr Eye Res. 2007; 32(6):501-9.

60. Kremmer S, Kreuzfelder E, Klein R, Bontke N, HennebergQuester KB, Steuhl KP, Grosse-Wilde H. Antiphosphatidylserine antibodies are elevated in normal tension glaucoma. Clin Exp Immunol. 2001; 125(2):211-5.

61. Maruyama I, Ohguro H, Ikeda Y: Retinal ganglion cells recognized by serum autoantibody against gamma-enolase found in glaucoma patients. Invest Ophthalmol Vis Sci. 2000, 41(7):1657-65.

62. Tezel G, Edward DP, Wax MB: Serum autoantibodies to optic nerve head glycosaminoglycans in patients with glaucoma. Arch Ophthalmol. 1999; 117(7):917-24.

63. Ikeda Y, Maruyama I, Nakazawa M, Ohguro H. Clinical significance of serum antibody against neuron-specific enolase in glaucoma patients. Jpn J Ophthalmol. 2002; 46(1):13-17.

64. Yang J, Tezel G, Patil RV, Romano C, Wax MB. Serum autoantibody against glutathione S-transferase in patients with glaucoma. Invest Ophthalmol Vis Sci. 2001; 42(6):1273-76.

65. Grus FH, Joachim SC, Bruns K, Lackner KJ, Pfeiffer N, Wax MB. Serum autoantibodies to alpha-fodrin are present in glaucoma patients from Germany and the United States. Invest Ophthalmol Vis Sci. 2006; 47(3):968-76.

66. Joachim SC, Reichelt J, Berneiser S, Pfeiffer N, Grus FH. Sera of glaucoma patients show autoantibodies against myelin basic protein and complex autoantibody profiles against human optic nerve antigens. Graefes Arch Clin Exp Ophthalmol 2008; 246(4):573-80.

67. Reichelt J, Joachim SC, Pfeiffer N, Grus FH. Analysis of autoantibodies against human retinal antigens in sera of patients with glaucoma and ocular hypertension. Curr Eye Res. 2008; 33(3):253-61.
68. Boehm N, Wolters D, Thiel U, Lossbrand U, Wiegel N, Pfeiffer N, Grus FH. New insights into autoantibody profiles from immune privileged sites in the eye: a glaucoma study. Brain Behav Immun. 2012; 26(1):96-102.

69. Schwartz-Albiez R, Monteiro RC, Rodriguez M, Binder CJ, Shoenfeld Y. Natural antibodies, intravenous immunoglobulin and their role in autoimmunity, cancer and inflammation. Clin Exp Immunol. 2009; 158(Suppl 1):43-50.

70. Shoenfeld Y, Toubi E: Protective autoantibodies: role in homeostasis, clinical importance, and therapeutic potential. Arthritis Rheum. 2005; 52(9):2599-606.

71. Schwartz M. Physiological approaches to neuroprotection: boosting of protective autoimmunity. Surv Ophthalmol. 2001; 45(Suppl 3): S256-S260.

72. Schwartz M. Protective autoimmunity as a T-cell response to central nervous system trauma: prospects for therapeutic vaccines. Prog Neurobiol. 2001; 65(5):489-96.

73. Huijbers A, Velstra B, Dekker TJ, Mesker WE, van der Burgt YE, Mertens BJ, et al. Proteomic serum biomarkers and their potential application in cancer screening programs. Int J Mol Sci. 2010; 11(11):4175-93

74. Nagele E, Han M, Demarshall C, Belinka B, Nagele R. Diagnosis of Alzheimer's disease based on disease-specific autoantibody profiles in human sera. PLoS ONE. 2011; 6:e23112.

75. Hueber W, Kidd BA, Tomooka BH, Lee BJ, Bruce B, Fries JF, et al Antigen microarray profiling of autoantibodies in rheumatoid arthritis. Arthritis Rheum. 2005; 52(9):2645-55.

76. Kokotas H, Kroupis C, Chiras D, Grigoriadou M, Lamnissou K, Petersen MB, Kitsos G. Biomarkers in primary open angle glaucoma. Clin Chem Lab Med. 2012; 50(12):2107-19.

77. Saccà SC, Centofanti M, Izzotti $\mathrm{A}$. New proteins as vascular biomarkers in primary open angle glaucomatous aqueous humor. Invest Ophthalmol Vis Sci. 2012; 53(7):4242-53.

78. Izzotti $\mathrm{A}$, Saccà SC, Di Marco $\mathrm{B}$, Penco S, Bassi AM. Antioxidant activity of timolol on endothelial cells and its relevance for glaucoma course. Eye (Lond). 2008; 22(3):445-53.

79. Fjell AM, Walhovd KB, Fennema-Notestine C, McEvoy LK, Hagler DJ, HollandD, et al. CSF biomarkers in prediction of cerebral and clinical change in mild cognitive impairment and Alzheimer's disease. J Neurosci. 2010; 30(6):2088-101.

80. Dickerson BC, Wolk DA. MRI cortical thickness biomarker predicts AD-like CSF and cognitive decline in normal adults. Neurology. 2012; 78(1):84-90.

81. Gupta N, Yucel YH: Glaucoma as a neurodegenerative disease. Curr Opin Ophthalmol. 2007; 18(2):110-4.

82. Lagreze WA, Gaggl M, Weigel M, Schulte-Monting J, Bubler A, Bach M, et al. Retrobulbar optic nerve diameter measured by high-speed magnetic resonance imaging as a biomarker for axonal loss in glaucomatous optic atrophy. Invest Ophthalmol Vis Sci. 2009; 50(9):4223-8.

83. Jonas JB, Schmidt AM, Muller-Bergh JA, Naumann GO. Optic nerve fiber count and diameter of the retrobulbar optic nerve in normal and glaucomatous eyes. Graefes Arch Clin Exp Ophthalmol.1995; 233(7):421-4.

84. Beatty S, Good PA, McLaughlin J, O'Neill EC. Echographic measurements of the retrobulbar optic nerve in normal and glaucomatous eyes. Br J Ophthalmol. 1998; 82(1):43-7.

85. Boles Carenini B, Tettoni E, Brogliatti B. CT and a echography of optic nerve in glaucoma. Acta Ophthalmol Scand Suppl. 2002; 236:40-1.

86. Dichtl A, Jonas JB. Echographic measurement of optic nerve thickness correlated with neuroretinal rim area and visual field defect in glaucoma. Am J Ophthalmol. 1996; 122(4):514-9. 
87. Kashiwagi K, Okubo T, Tsukahara S. Association of magnetic resonance imaging of anterior optic pathway with glaucomatous visual field damage and optic disc cupping. J Glaucoma. 2004; 13(3):189-95.

88. Wang MY, Wu K, Xu JM, Dai J, Qin W, Liu J, et al. Quantitative 3-T diffusion tensor imaging in detecting optic nerve degeneration in patients with glaucoma: association with retinal nerve fiber layer thickness and clinical severity. Neuroradiology. 2013; 55(4):493-8.

89. Perry VH, Oehler R, Cowey A. Retinal ganglion cells that project to the dorsal lateral geniculate nucleus in the macaque monkey. Neuroscience. 1984; 12(4):1101-23.

90. Weber AJ, Chen H, Hubbard WC, Kaufman PL. Experimental glaucoma and cell size, density, and number in the primate lateral geniculate nucleus. Invest Ophthalmol Vis Sci. 2000;41(6):1370-9.
91. Yücel YH, Zhang Q, Weinreb RN, Kaufman PL, Gupta N. Atrophy of relay neurons in magno- and parvocellular layers in the lateral geniculate nucleus in experimental glaucoma. Invest Ophthalmol Vis Sci. 2001;42(13):3216-22.

92. Gupta N, Greenberg G, Noel-de-Tilly L, Gray B, Polemidiotis M, Yucel YH. Atrophy of the lateral geniculate nucleus in human glaucoma detected by magnetic resonance imaging. $\mathrm{Br} \mathrm{J}$ Ophthalmol. 2009; 93(1):56-60.

\section{Corresponding author:}

Alameda Madeira, 258 - sala 1206 -Alphaville - Barueri - SP CEP: 06454-010

Email: nirokasahara@hotmail.com 